\title{
REVIEW OF THE BOOK: Braveboy-Wagner, J.A. (Ed.). (2016). Diplomatic Strategies of Nations of the Global South. The Search for Leadership. New York: Palgrave-Macmillan, 453 p.
}

\author{
A.A. Eremin, A.V. Tsvyk, V.I. Yurtaev \\ Peoples' Friendship University of Russia (RUDN University), \\ Moscow, Russian Federation
}

The collective work under the editorship of Jacqueline Anne Braveboy-Wagner is nothing less than a practical fruit of Global South Caucus of the International Studies Association, quite famous around international relations scholars worldwide. Needless to say, the topic chosen for the book is of high importance due to the rising popularity of Global South concept in the last decade. As a proof of that - the book has been published by Palgrave Macmillan, which confirms the significance of the chosen topic and also guarantees a serious outreach around the globe. The book primarily targets to fill the gap on foreign policy research regarding the developing nations of Global South. The main advantage of this collective work is the initial dedication to combine both highly theoretical and practical approaches of foreign policy and diplomacy analysis in order to make the work useful for both academic and expert communities. According to the editor, most essential criteria for such a noble target was to ensure the participation of only those specialists, who either live and conduct their research in the abovementioned countries or have strong direct work ties with the scholars form these nations. Notably, the book aims at amplifying the popularity of the Global South topic among northern researchers, as well as creating a working network for both younger and older scientists interested in working on numerous Global South topics.

\section{LATIN AMERICA}

When touching upon diplomacy strategy of potential global powers, the book presents us with a curious example of Brazil. In this regard authors outline a conceptually important moment - one of the leading nations of the Global South only recently has learned to appreciate that foreign policy and diplomacy are not quite the same thing. Diplomacy of the country has for ages existed in a framework of Ministry of Foreign Affairs being considered its only instrument. At the same time the primary mechanism for influencing world politics for Brazil is argued to be based on J. Nye's concept of soft power, which according to the authors makes great contribution to enhancing Brazil's role in current configuration of the International Relations system. On top of thorough analysis of Brazil's culture, economy, history and political system authors get to the idea, that Brazil does have a future as an important power in the international 
arena not just in the context of Global South, but on a much bigger scale as well. The future of that, however, depends very much on one simple thing - finding a "common language" with Brazil's most important partners [Braveboy-Wagner 2016: 31]. Mainly that refers to the necessity to make cordial format of relations with number of other Global South nations more pragmatic and oriented towards mutual gain, rather than free giveaways. At the same time there is a reasonable concern that despite the readiness to project cordiality and good will towards extra-regional actors, inside the region the situation is still marked by mistrust, even though Brazil puts a fair share of effort to establish and develop regional cooperation. And while regional support is not precisely an essential condition for political leadership on a global scale, considering all the odds it is a great advantage for a developing country. Yet the most profound issue for Brazilian diplomacy according to the book is for the diplomatic corps to catch up with the ongoing societal changes. It includes a dire need to provide new ideas and values, expand institutional mechanisms of influence and raise professionalism of diplomatic personnel — all of which is claimed to help form a more organized approach to Brazilian diplomacy. In this chapter to analyze the development of Brazilian diplomacy authors mainly address the period of "Left turn", mainly characterized by the presidencies of Lula da Silva and Dilma Rousseff, marking this period as a beginning of more proactive foreign policy, which also became closely linked with domestic policy as well. In general authors tend to perceive these presidencies as positive for the development of diplomacy of Brazil, which is especially interesting in the context of most recent changes in political system of the country and corruption cases, that concluded in trials and even incarceration of the above-mentioned leaders [Braveboy-Wagner 2016: 51 - 52].

Another example of Global South nation in Latin America is Venezuela, which unlike Brazil is presented more as a regional leader rather than a potential global one. Even though the book starts with the historic overview of how diplomatic strategy of Venezuela developed thought time, it mainly concentrates on the most recent period starting with the presidency of Hugo Chavez. Authors touch upon two general foreign policy concepts that were developed and implemented in this period of time: "Soft balancing" and "Hard balancing" [Braveboy-Wagner 2016: 265]. Despite the fact that Venezuela was primary provider of hydrocarbons to the US market, ideologically this country maintains a rather defiant anti-American orientation when it comes to military and ideology. This contradicting positions evidently need certain mechanisms to effectively coexist in terms of national foreign policy and trade, and soft and hard balancing concepts according to the authors are the key elements to this equation. The main target of "Soft balancing" is to increase regional autonomy in Latin America, provide an effective alternative model of cooperation, organizations, integrational formats for the region in order to weaken the hegemonic position of US and raise the cost of its foreign policy in the Hemisphere. To achieve that Venezuela aimed at promoting new cooperation approach aimed at tackling a vast number of social and development problems, which generally are considered a priority for the developing countries of Latin America. The intensification of regionalization process thus is supposed to gradually and nonviolently push out dominant Washington's influence, which would automatically grant 
all the countries of the region to conduct more independent and autonomous foreign policy courses [Braveboy-Wagner 2016: 267].

"Hard balancing" - another approach that focuses on the increase of military capacity and role of armed forces in the country in accord with the asymmetrical war doctrine. Even though originally it is supposed to complement the soft balancing in reconfiguring the influence of the US in the region, it generally means being ready to use real power when necessary [Braveboy-Wagner 2016: 269]. Interestingly, due to the historic specificity of the region, the rising role of military in the political life of a state is usually perceived to be a negative process in Latin America; when in case of Caracas it serves to amplify alliances, rework foreign policy concepts and external trade priorities.

Authors argue that in terms of political leadership in the region Venezuela for a period of time was a significant actor comparable to the caliber of Brazil, mainly because the abundancy of hydrocarbons and relatively high prices for them at the time. It allowed Caracas not only to amplify social policy and target social inclusion issues, but also to quite successfully stay afloat during the 2008 financial crisis. However, recent events that followed the death of ever charismatic leader Hugo Chavez, including the raging inflation and rapidly progressing social, political and economic crisis on a national scale - are quite evidently demonstrating the inability of Venezuela to claim the regional leadership. Due to this the book even suggests that Caracas is a "regional leader with the feet of clay", meaning that the geopolitical vision of the world and complex attempts to recalibrate the existing regional or global political balance poorly coexist with unbalanced economic system, based on selling mineral resources to the hostile political power, and domestic policy that lacks consistency and stability. Authors conclude, that since 2016 Caracas maintains ambitious political rhetoric in the international arena, but without former efficiency of "petro-diplomacy" to sustain it there is little chance for Venezuela to successfully carry out own regional and extra-regional agenda [Braveboy-Wagner 2016: 284]. On top of that the recent "right" turn of Argentina and Brazil there is yet more obstacles for the spreading of the Venezuelan influence in Latin America.

Another good insight into different models of diplomacy among the Global South nations In the Western Hemisphere is Cuba. In the book it is marked as a sub-regional leader, and at the same time authors outline the main distinctive feature of the Cuban diplomacy — small territory and various considerable vulnerabilities and dependencies do not undermine its foreign policy impressive capabilities. By adopting a set of efficient and pragmatic concepts, Cuba managed to ensure a serious global political presence for a state with such prolific domestic issues. Here the book concentrates on the analysis of four types of diplomacy that Cuba adopts to widen its political influence in the Global South: regionalism, multilateralism and internationalism, medical diplomacy, and public diplomacy [Braveboy-Wagner 2016: 322]. The main narrative in this regard is the timely transition of Cuban diplomacy from the ideological basis to a more pragmatic approach based on soft power with obvious attention to humanitarian and development cooperation, including medical assistance. Although the degree of critique of diplomacy systems 
of sub-regional and exclusively regional powers in the book is generally lower than that of the potential global leaders, in terms of Cuba authors made an emphasis on the prognosis that Cuba is most likely to remain massively limited in projecting political influence abroad. Even though current diplomacy model seems to be demonstrating impressive results, it is the profound economic challenges that limit any further development for this country in terms of amplifying its role in intra and extra-regional politics. On top of that authors make a conclusion that lack of Allies and low dedication to demonstrate full-scale practical support among existing international sympathizers cripple the capabilities of Cuba to outgrow the role of a potential sub-regional leader and adopt new formats and mechanisms of foreign policy. At the same time authors suggest that while being undoubtedly crucial, factors like lack of resources, economic layout and external political pressure cannot truly be labeled as defining for the current challenges that Cuba experiences in the international arena [Braveboy-Wagner 2016: 329]. Cuba in the recent years had managed to strengthen and revitalize relations with traditional partners as well as establish new connections as well. Even the United States since 2015 have made several steps towards reloading the traditionally tense dialogue with Havana. The book argues that the core issue for Cuba in general is the governments reluctance to accept political and societal changes and initiate the formation of civil society. Constant crackdowns on opposition, demonstrative exclusion of non-governmental actors from the political process and disregard for human rights instills understandable criticism into potential partners [Braveboy-Wagner 2016: 338]. In combination with serious mistrust of Cuban political elite towards Washington this becomes one of the hardest obstacles on the road to once and for all overcome Cuban regional and global isolation.

\section{ASIAN-PACIFIC REGION}

In terms of Global South countries in the Asian-pacific it is impossible not to mention China. Chapter 3 "Aspiring to Be a Global Power: China's Activism in the Global South" analyses the role of Global South vector in the foreign policy of China alongside with the its' diplomatic strategies in the context of the countries' integration in the contemporary global governance system. According to the author of the chapter, $\mathrm{mr}$. J. Char, foreign policy of China under Xi Jinping became more pro-active due to the implementation of multilateral diplomacy, Chinese activities in UN, peacekeeping, creation of ambitious geo-economic projects (Belt and Road Initiative) and financial institutes [Braveboy-Wagner 2016: 60]. The book outlines that China positions itself as a developing nation even though it currently is the second largest economy in the world and provide significant aid to the countries of Asia, Africa and Latin America. Among the most essential interests of China in the sphere of international cooperation the book names the following: the need to promote the One-China policy globally, maintaining border security by implementing peripheral diplomacy with the Asian countries and ensuring new energy resources markets of Africa and Latin America to stimulate export-oriented economy [Braveboy-Wagner 2016: 65]. Thus, the predominance of purely pragmatic approach towards the Global South vector of Chinese foreign 
policy grants a number of advantages compared to the activities of the western countries. The book states that the basic principles of the Chinese foreign policy towards the Global South had been formed during Mao Zedong, when 5 principles of peaceful coexistence were announced. Under Deng Xiaoping with his "Socialism with Chinese characteristics" China had guaranteed itself an environment favorable to the economic growth and reintegration into the global economy. Subsequent leaders introduced the definitions of "peace" and "development" as important postulates for the international cooperation of China in the bipolar world. Under Xi Jinping Chinese diplomacy has been extended by the orientation towards the mutual gain and abandonment of zero-sum game principle [Braveboy-Wagner 2016: 66].

Further in the text the author of the chapter conducts thorough analysis of the modern diplomatic strategies of China, which include "Developmental" Economic Policy. By giving comprehensive examples the author concludes that Global South countries can be considered the main targets of China's mutually beneficial economic diplomacy. According to the author, the "Soft" Security Policy of China is based on peacekeeping (under UN) and mediation (like in the case of Sudan and Myanmar) roles of China in the resolution of international conflicts on top of the efforts to combat nontraditional threats to global security (Ebola case, piracy and etc.); all of which is mostly targeted towards helping the countries of the Global South. However, the key component of the foreign policy of China is the Multilateralist Policy that forms the key. On top of that China's self-identification as a developing state of the Global South amplifies its influence in the international arena [Braveboy-Wagner 2016: 70]. Among the internal and external factors that define China's foreign policy the author names Global governance structure and its effect on national interests of China; bureaucracies and personal preferences of the ruling party and nationalism.

However, on its way to acquiring the status of the global power, China encounters certain issues regarding its relations with other Global South nations. Among those "Chinese threat" thesis and general anti-Chinese position of the local populations in the countries where Chinese companies work on multiple infrastructure projects. In the conclusion of the chapter it is noted that cooperation of China with the countries of the Global South can be marked as an example of the transformation of the global governance system that can serve as an alternative to the presumably universal Western model of development [Braveboy-Wagner 2016: 80].

Another country in the region mentioned in the book under the Global South diplomacy strategy analysis if Singapore. Even though not as politically potent or ambitious (and thus unable to compete for global leadership), this country nonetheless has successfully portrayed itself as a potential regional leader and is often set as an example of unprecedented economic and development success of a small nation. Chapter 15 "The Diplomacy of Singapore: Rationality and Pitfalls" takes a close look into the basic determinants of the Singapore's foreign policy starting with its independence in 1965. While reviewing theoretical basis of Singapore foreign policy and outlining the scarcity of territories, author mentions virtual enlargement of the role of Singapore via political mediation in United Nations and ASEAN and promotion of its economic model of development among the Global South countries [Braveboy-Wagner 2016: 418 — 419]. 
Another interesting case from the book is India. It is the world's most populous democracy and second most populous country, the ninth largest economy in the world. India could be described as an emerging power, a regional power, a global power, a great power, and a would-be great power. At the time, on the global level, India has refused to build any traditional sort of "military alliance" either with or against the USA. Nevertheless, India continues to play a leading role in the global south and "Strategic restraint". The authors outline India's ability to expand its relationship with the ASEAN states, which is a key factor in the larger power play in the Indo-Pacific, given the dominance of China in the subregion. The challenge of trust in the region unable India to craft careful policies in dealing with Pakistan and China [Braveboy-Wagner 2016: 98]. India is gearing up and moving toward staking a global claim but has to make sure that this course of actions would be in line with its core national security and strategic interests.

\section{AFRICA AND MIDDLE EAST}

In the region sliding into chaos, Egypt looks relatively stable. Although Egypt's geostrategic environment deteriorated as the country was surrounded by dysfunctional states - Libya, Sudan, Iraq, Syria and Palestine - which increased Egypt's vulnerability to threats of international terrorism and weapons smuggling through its territory. That is why Egypt is included in the process of implementing the new doctrine of regional security based on military force. The future of the Middle East region will be determined by the ability of Russia and China to fill the emerging vacuum and by regional powers, namely Egypt, Iran, Turkey and Saudi Arabia. Achieving common positions in order to form a stable regional system of international relations will require a dialogue between these competing countries. According to the Chapter 6 "Egypt as a Leading Nation: Regional Imperatives and Domestic Constraints", Egyptian diplomacy, which has a history of proven success in resolving contradictions, will allow Egypt to occupy a worthy place in this system as an intermediary, as well as a mediator to reach a political solution for the conflicts in Syria and Gaza [Braveboy-Wagner 2016: 158]. Egypt has been using branding strategies in order to establish itself as a regional power to build its image globally. Egypt's regional status has been largely built on its soft power. In any case, Egypt may not be able to be an undisputed regional leader. However, two difficult questions have to be solved for this: confrontation of Egypt with Turkey and Qatar and internal confrontation within the country with the Muslim Brotherhood. The inclusion of the latter in the strategic plans of the United States and Saudi Arabia to create a Sunni coalition against Shiite Iran can reduce the severity of the problem and increase Egypt's ability to attract financial resources to solve its domestic economic problems.

Speaking about Iran, researchers, above all, point to its potential as one of the most promising key players in the Persian Gulf and the Middle East, and more over stressed in the Chapter 7 "Iran's Permanent Quest for Regional Power Status" that "the permanent objective of Iran is to become a key player in the region, not just in the Persian Gulf but also in the greater Middle East and Central Asia" [Braveboy-Wagner 2016: 182]. They argue that "Iran has fulfilled, both during the era of Shah Reza Pahlavi and during 
the era of the Islamic Republic, the role assigned to it as a middle power", which act to create and maintain a favorable regional context while aspiring to a global presence. As rightly noted, Iran's withdrawal to the role of the new leader in the region was due to the overthrow of Saddam Hussein's regime in Iraq and the defeat of the Taliban but this favorable situation was mainly attributable to the US intervention rather than a successful Iranian diplomacy [Braveboy-Wagner 2016: 186].

The process of decision-making in Iran from the outputs of foreign policy was a single person decision mechanism either during the times of the Shah or since the establishment of the Islamic Republic. President Rohani, with the "resistance economy" and the "heroic flexibility" concepts introduced by Khamenei in 2012 and 2013, managed to become an exponent of both parts of the modern Iranian elite. Special attention is paid to the consideration of the specifics of Iranian regional strategy and diplomacy. The problem of independence of Iran and the need to ensure it was reflected in Iran's use of various approaches to diplomacy, such as "positive equilibrium", "negative equilibrium", "third power diplomacy", "positive nationalism", "nonalignment", and "independent national policy" as well as "pragmatism", "multilateralism", and "regionalism". The basic principles of Iranian foreign policy from the time of the revolution are as follows: independence from the East as well as the West; designating the USA as the principal enemy of Iran; fighting against superpowers and the Zionist power; supporting all the oppressed peoples throughout the world, especially the Muslim ones; liberation of Jerusalem; anti-imperialism, support of the oppressed masses [Braveboy-Wagner 2016: 199]. All these ideological principles are deeply influenced by a "mixture of an innovative Shia religious doctrine and a revolutionary ThirdWorldism and anti-imperialism". The region around Iran since pre-revolutionary times is of geographical priority for Iranian foreign policy and area of its strategic interest. Dealing with most "global south nations" Iran claim to be the state that guarantees stability and security in the Persian Gulf but ideological and religious contention since the revolution generate distrust among its neighbors, priory the conservative Gulf states. Moreover, the regime's ideological and anti-system stance started the strategic alliance with Assad in Syria and the alleged support for Houthis in Yemen. Yet the same factor led to direct confrontation with the Saudi Arabia and Egypt. Islamic Republic, especially after the Iran-Iraq war, manage its diplomacy more carefully using mixture of hard and soft power instruments to try to overcome regional distrust [Braveboy-Wagner 2016: 188]. It is noted that since the late 1970s Iran has been associated with an ideological component in international relations in the region.

The author also indicates two new discourses, made by President Khatami and Ayatollah Khamenei: the call for the promotion of confidence-building measures in the Middle East and Gulf countries (Khatami 1997), and the second - for ending the ideological struggle of the Islamic Republic vis-à-vis other Islamic states (Khamenei 1997). During Ahmadinejad's neoconservative period in Iran several new postures in foreign affairs was inaugurated and IRI "gained a major boost among the nonaligned countries at a time of ostracism by the major powers". It is important, that Iran could not emerge unharmed from long-term sanctions. And only in 2015 Iran possesses competitive 
economic capabilities in relation to others in the Middle East with a supervised nuclear program that can foster its global prestige. The nuclear negotiations in Geneva represented a diplomatic victory. Iran obtained international recognition of its nuclear program and was recognized as a necessary interlocutor in resolving regional conflicts such as the Syrian civil war. Taking into account its "soft power" Iran certainly could be among the global south countries in the 2000s. Its "Dialogue of Civilizations" initiative (1997) that was accepted within the Islamic Conference and the United Nations (UN) shows that Iran also is a state with "great power" aspirations. The chapter concludes that "although Iran has been well placed historically to play a leading role in the Middle East, it has clearly faced some challenges stemming from the way it has been inserted into and interacted with the regional and international systems". Finally, it is stated that Iran succeeded in projecting itself as a regional leader in the Middle East since the 1970 s, nevertheless "it has not yet been able to attain a consistent leadership role, primarily because the perception of Iran regionally and internationally and its capacity to project itself successfully has been so dependent on systemic factors" [BraveboyWagner 2016: 205]. The influence of internal processes (internal balance of power, the Iranian public's views, and the reciprocal relations between society and regime) on foreign policy of Iran must be taken into account by decision makers in the West in designing their policy toward Iran.

In Chapter 13 the authors consider globally active foreign policy path of Qatar after 1995. The authors underlined that "global activism" model of the foreign policy was pursued by Qatar neither because of imminent military and economic security threats or the need to protect sovereignty. After 2014 its onset was attributable to the conflation of complexities in Arab Spring revolts, intra-Gulf politics and Qatar's domestic societal reactions. Thus, Qatar showed that "global activism could not be pursued without increased security costs; pursuing ambition required adjustments in strategies" [Braveboy-Wagner 2016: 365].

Among the African countries Nigeria, the most populous country and the largest economy on the African continent, has maintained a fairly consistent foreign policy since its independence in 1960 . The country has variously been described as "a regional hegemon", "Africa's most powerful nation", "the giant in the sun of Africa", "the crippled giant", and locally as "Big Brother". As it underlined, against the backdrop of the rollback of democracy in several countries of the continent, Nigeria has certainly gained greater regional legitimacy by democracy [Braveboy-Wagner 2016: 214]. But although Nigeria wishes to be perceived as a non-threatening leader in the region and continent, its size and proactive diplomacy have sometimes had the opposite effect of making its neighbors wary of its hegemony. However, there are challenges to its leadership (urgently needs to promote good governance by tackling corruption, provide efficient power sector for industrial production, transform the country's dilapidated infrastructure as well as address the problems of terrorism and youth unemployment). Nigeria is one of the two African giants capable of playing leading roles in advancing US foreign policy goals in Africa. It is stressed, that if Nigeria wishes to fulfill its role as a regional hegemonic power and to benefit from the current process of global economic integration, 
"it must not just continue its peacekeeping/peacemaking role in the region but also enhance its soft power capabilities to support its domestic and diplomatic initiatives". This calls for a coherent government strategy that will underscore a responsible foreign policy and domestically, long-term, sustainable development. The democratic enhancement instead of military dictatorship and institutional, technological, and diplomatic reforms and capacity-building programs will create a favorable image of Nigeria in the galas of the international community. They authors of the Chapter 8 "Nigeria's Diplomacy: The Challenges of Regional Power and Leadership in a Globalizing World" argued that the key question for Nigeria is: how well is Nigeria positioned to sustain its leadership role in Africa and to remain competitive in an age of globalization? Nigeria needs to seize the opportunity for a greater projection at the sub-regional, continental, and global levels [Braveboy-Wagner 2016: 233].

Uganda forms part of the GLR, EAC, and the Greater Horn of Africa and it plays a strategic role in regional security in all of them. The authors outline that being landlocked, and smaller in size compared to neighboring countries, Uganda has taken advantage of its location by acting as the continental bridge between Anglophone and Francophone Africa and between Arab Africa and Black Africa, aspiring to regional hegemony. At the same time the political and economic exclusion of Northern and Western Uganda have exposed these areas to endless cross-border conflicts [BraveboyWagner 2016: 240]. Analyzing the features of Uganda's strategies, a focus on alternative development thinking is useful, highlighting the expectations of Uganda's movementocracy and related ideas and activities at the regional and international levels. In Chapter 9. Uganda: A Mix of Strategies for Soft Power the factor of its complicated relations with its neighbors in East Africa and the Great Lakes region (GLR) is underlined. Kenya, Uganda, and Tanzania arguably all can claim to play leadership roles in East Africa. Among them Uganda has perhaps carved out the most aggressive position in terms of its regional foreign policy. In contemporary Uganda Museveni's regime has had to project both hard and soft power in the region because of the priority of assuring domestic and national security in building the nation. Uganda's overarching diplomatic strategy can be described as "activism of small states," under which foreign policy is used as an instrument of nation building and consolidation. In this regard, at the regional level Uganda has been a strong supporter of economic and political integration in the context of the EAC. Cultural factors and presidential control may operate in combination in Ugandan regional policies when ethnic factors are taken into account. [Braveboy-Wagner 2016: 256]. Uganda has also promoted itself as a regional peacemaker. Beyond the region, Uganda has been proactive at the UN, seeking out prominent diplomatic positions. Furthermore, in view of the emergence of new global economic power centers, Uganda plans to take advantage of China, Brazil and India.

According to the authors, South Africa is not only a leading developing state but also is the leader in the wider global arena. The South Africa concept of "leading global south nation" forms the basis of the strategy of the presence of South Africa in world politics, or "the aspiration is for South Africa to influence international relations at the global level, in order to advance the interests of itself and its region". As it is shown 
in Chapter 5 the commitment to a South and African-focused foreign policy has become one of the distinguishing features of South Africa's foreign policy. Today, multilateralism remains foundational to South Africa's foreign policy as well as the soft power. South Africa uses both the development assistance and military capabilities to advance its image as a peacemaker and a responsible regional leader. The authors conclude that a "multipronged foreign policy approach of ambiguity that allows for ad-hoc decision-making based on what policymakers perceive to be in the national interest at any given time might just be the only possible strategy for a state that is still struggling to come to terms with its identity and its national interests" [Braveboy-Wagner 2016: 146].

\section{CONCLUSION}

Overall, we can conclude, that despite certain imperfections the book seems to tackle the targets that has been put before it. Most important achievement of the book, in our opinion, is the variety of nations, foreign policy courses and diplomatic strategies that have been analyzed and put together. The structure of the book allows to grasp the main similarities and differences of Global South nations on different levels when it comes to establishing and maintaining their international ties. The book demonstrates, that in fact there is no unified and homogeneous Global South, instead there is a number of developing nations, whose targets seem to gain similarity with each year. The book offers two main conceptual ideas.

First, former approaches towards researching International Relations, that marked small nations' foreign policies as insignificant, inevitably lose support among IR researchers. By now It indeed should be clear enough that the experience of the Global South nations can make International Relations more inclusive and guarantee a better understanding of this field of study.

Second, quite popular among IR scholars classic realist security-oriented approaches and liberal institutionalism cannot be fully implemented in relation to the developing nations of the Global South and require certain adjustments. No current IR theory can neither truly explain the political processes happening in the Global South countries, nor incorporate and seriously take into the account all the diversity of unique local narratives out there. It is not possible to fully reveal, for example, the influence of the confessional factor and inter-confessional competition on the development of the transformation process of modern international relations with the participation of the countries of the South. Despite all that, most importantly, the book seeks to motivate young scholars to seek beyond the so-called "Western safe-zone" in their research; for those new sources can provide "innovative local histories, influences and strategies" necessary to ensure a more comparative basis for studies in the sphere of International Relations and foreign policy analysis.

\section{REFERENCES}

Braveboy-Wagner, J.A. (Ed.). (2016). Diplomatic Strategies of Nations of the Global South. The Search for Leadership. New York: Palgrave-Macmillan, 453 p.

Received: 15.08 .2018 
For citations: Eremin, A.A., Tsvyk, A.V. \& Yurtaev, V.I. (2018). Review of the Book: BraveboyWagner, J.A. (Ed.). (2016). Diplomatic Strategies of Nations of the Global South. The Search for Leadership. New York: Palgrave-Macmillan, 453 p. Vestnik RUDN. International Relations, 18 (3), 716-726. DOI: 10.22363/2313-0660-2018-18-3-716-726.

\begin{abstract}
About the Authors: Eremin Arkadiy Alekseevich - $\mathrm{PhD}$, assistant at the Department of History and Theory of International relations RUDN University (Peoples' Friendship university of Russia) (e-mail: 79151775018@yandex.ru).

Tsvyk Anatoliy Vladimirovich - PhD, Senior Lecturer of the Department of Theory and History of International Relations, RUDN University (Peoples' Friendship university of Russia) (e-mail: tsvyk-av@rudn.ru).

Yurtaev Vladimir Ivanovich - Doctor of History, Professor of the Department of Theory and History of International Relations, RUDN University (Peoples' Friendship university of Russia) (e-mail: yurtaev-vi@rudn.ru).
\end{abstract}

\title{
РЕЦЕНЗИЯ НА МОНОГРАФИЮ: Diplomatic Strategies of Nations of the Global South. The Search for Leadership / Ed. J.A. Braveboy-Wagner. New York: Palgrave-Macmillan, 2016. 453 p.
}

\author{
А.А. Еремин, А.В. Цвык, В.И. Юртаев \\ Российский университет дружбы народов, \\ Москва, Российская Федерация
}

Дата поступления статьи: 15.08.2018

Для цитирования: Еремин А.А., Цвык А.В., Юртаев В.И. Рецензия на монографию: Diplomatic Strategies of Nations of the Global South. The Search for Leadership / Ed. J.A. Braveboy-Wagner. New York: Palgrave-Macmillan, 2016. 453 p. // Вестник Российского университета дружбы народов. Серия: Международные отношения. 2018. T. 18. № 3. С. 716-726. DOI: 10.22363/23130660-2018-18-3-716-726.

Сведения об авторе: Еремин Аркадий Алексеевич - кандидат исторических наук, ассистент кафедры теории и истории международных отношений Российского университета дружбы народов (e-mail: 79151775018@yandex.ru).

Цвык Анатолий Владимирович - кандидат исторических наук, старший преподаватель кафедры теории и истории международных отношений Российского университета дружбы народов (e-mail: tsvyk-av@rudn.ru)

Юртаев Владимир Иванович - доктор исторических наук, профессор, профессор кафедры теории и истории международных отношений Российского университета дружбы народов (e-mail: yurtaev-vi@rudn.ru) 